\title{
10. Playing politics with knowledge: the works of multiple actors within IGAD PLUS
}

\author{
Kuyang Harriet Logo
}

\section{INTRODUCTION: ACTORS AND INTERPRETATIONS}

Before the independence of South Sudan on 9 July 2011, the Sudan had a turbulent history and had experienced two civil wars. The first civil war was waged between 1955 and 1972 and the second civil war was waged between 1984 and 2005. The second civil war came to an end when the Intergovernmental Authority on Development (IGAD) ${ }^{1}$ with the assistance of Troika, which is comprised of the United Kingdom (UK), the United States (US) and Norway, mediated the Comprehensive Peace Agreement (CPA) of 9 January 2005. The CPA provided for a referendum allowing South(ern) Sudan to choose whether to remain united with the Sudan or become independent. After a successful six-year interim period which ended in 2011, the South overwhelmingly voted to separate from the Sudan in the same year. The South eventually became independent on 9 July 2011. On 15 December 2013, two years after independence, South Sudan's civil war started (De Vries and Schomerus, 2017). Since independence, South Sudan remains embroiled in a senseless war and disarray. The situation in South Sudan is "more than a breakdown of the rule of law and order" (Mamdani, 2016). The violence is political. IGAD, and later IGAD PLUS, again intervened as mediators and the Agreement for the Resolution of the Conflict in South Sudan (ARCSS), including its stipulations on transitional justice and the establishment of the Hybrid Court for South Sudan (HCSS), was signed on 17 August 2015.

The consequences of the civil war have been devastating, yet there has been a lack of accurate reports on the level and details of the violence and destruction. Reports from the United Nations (UN), the African Union (AU), the European Union (EU) and Troika show that human rights violations marred the trajectory of the conflict. Both parties to the conflict, including their allied militias, committed human rights violations with systematic impunity 
(Dessalegn, 2017). Such reports indicate that over 400,000 people have been killed, with thousands forced to seek refuge and some living as internally displaced persons in the Protection of Civilian sites (PoCs), but little detail has been provided on how these analyses arrived at their figures (ibid.).

As early as 19 December 2013, when the conflict erupted, IGAD convened an extra-ordinary meeting to respond to the crisis in South Sudan. Upon intervening, IGAD appointed three envoys to structure the mediation of the South Sudan conflict and set up the Joint Monitoring and Evaluation Commission (JMEC) to monitor compliance of the parties to a ceasefire agreement. Besides IGAD, the AU also intervened in support of IGAD, but each actor did so within its own mandate and the extent to which the two coordinated the peace mediation was unclear, indicating a likely lack of coordination (Vertin, 2018).

From the very onset of intervention by IGAD and later IGAD PLUS, ${ }^{2}$ the conflict was labeled an ethnic conflict sparked by political differences between factions of the ruling elite. The dominant conceptualization of the conflict as an ethnic one arising out of a political stalemate inhibited regional actors from providing a complete analysis of the deeply rooted animosities in South Sudan (De Vries and Schomerus, 2017). Moreover, the root causes of the conflict are multiple, but little analysis of these causes has fed into how IGAD and later IGAD PLUS intervened in the conflict. For instance, as soon as independence was attained, the government became increasingly corrupt, kleptocratic and intolerant to dissent. Political power was used to secure public resources for individual projects. A lack of inclusive participation, weak institutional capacity and a disinterest in nation building, combined with a focus on the instrumentalization of ethnicity, compounded the challenges of the new nation. However, during the mediation of the conflict, and in the final peace accord, none of these root causes was discussed, except for the political differences within the Sudan People's Liberation Movement (SPLM) (Dessalegn, 2017).

The chapter which follows elaborates on these difficulties with regards to knowledge production for transitional justice in the non-transition context that emerged from the CPA. In particular, it looks at the challenges in establishing the transitional justice process, and especially the HCSS, as they unfolded in the process of mediating and implementing ARCISS and the revived 2018 agreement. It does so by applying the processes and politics of knowledge, its production, management, coordination, use and dissemination, as well as knowledge gaps, as entry points for the discussion of how the intense regional geopolitics of the immediate neighbors of South Sudan, and the IGAD PLUS actors, have overwritten concerns for knowledge- or evidence-based policy-making. In doing so, the chapter highlights the impact of the intersection of knowledge and power on the resolution of the conflict, the peace negotiations and on (the possibility of) criminal accountability. While the multiple knowledge actors within IGAD PLUS eventually delivered on the 
peace agreement, the politics of knowledge and regional geopolitics within the region inhibited the establishment of the HCSS (Knopf, 2018).

\section{SOUTH SUDAN AS A NON-TRANSITION STATE}

In transitional justice theory and practice, political shifts are anticipated to take a particular form, like a transition to democracy. In conceptualizing transition, terms like the transfer of power, regime change, restorations, political development or political transition itself may be appropriate. Whatever change or transition is, key transitional justice scholars suggest that it has to include a transition to democracy and the undertaking of democratic reforms including the initiating of civilian rule. Transition would also entail that a system respects the rights of citizens and becomes intolerant to citizen abuse (Arthur, 2009). The history of transitional justice and its ideologies were rooted in liberal democratic transitions that occurred in Latin America as well as in the legal innovations of the Tokyo and Nuremburg trials. Over time, the normative focus of the field became more preoccupied with justice for victims of human rights violations, truth telling and reparations. While the assumptions that shaped the field, its policy and practice, originated from contexts where political and democratic transitions occurred, in contexts where no such transitions were experienced, transitional justice implementation has faced significant challenges. For instance, in contexts where political and democratic transitions failed or did not occur at all, we see demand for justice after conflict either halted or approached differently altogether (Sharp, 2015). The Sudan is a good example of such a case where justice was attempted and failed because no transition had occurred. The International Criminal Court (ICC) sought to indict Omar al-Bashir for the genocide in Darfur when he was still the sitting head of state in the Sudan, but failed to move forward with the case because al-Bashir used his political power to frustrate the ICC's move (Rothe, 2007). The challenges in trying to indict a sitting head of state by the ICC are well documented and provide good lessons for South Sudan (Rothe, 2007). As I will elaborate here, none of what is envisaged in a transition to democracy and civilian rule has occurred in South Sudan.

When the CPA was signed in 2005, amid a myriad of challenges, a transitional period of six years as an integral part of the peace process was initiated. In a context where there was no functional state and no functional institutions, there was nothing to fail, except the anticipated transition itself (Mamdani, 2016). Therefore, while justice remained elusive in South Sudan and while attempts were made to include criminal accountability for crimes committed, such calls for accountability were ignored. For instance, the mediators of the CPA avoided all notions of criminal accountability despite calls to bring perpetrators of human rights violations to book. In the end, the CPA placed 
the country in the hands of an unaccountable clique. As a result, South Sudan emerged from the CPA with no (democratic) institutions of any form, except old colonial systems that continue to function alongside the Sudanese systems. After the CPA, the oil money began to trickle into an informal economy and into the hands of political elites. Economic transformation of ordinary citizens' lives did not happen. Additionally, patronage networks increasingly correlated with ethnicity and identity politics in a system where ethnicity was institutionalized, and closely linked to territoriality and belonging. Therefore, the issue of ethnicity became more complex than just the understanding construed around the Dinka-Nuer dynamics. Compounded by a failed security sector reform and rural insecurity, the weak state capacity to manage violence and contain rebellions made shifting alliances more plausible and complicated. South Sudan's weaknesses and the influence of international actors undermined state legitimacy, a pattern which has been repeated every time there is a crisis in South Sudan (Rolandsen, 2015).

With a failed transition at hand came the tough question of how to deal with the situation in South Sudan - a question that has been asked in many other non-transitioning contexts. For instance, the key and yet most intractable questions gravitated around how the newest state could avoid being compromised in the struggle for democracy and how the perpetrators of violence and the leadership could be sent to trial without necessarily jeopardizing a fragile sovereignty. There were no easy answers to these questions. Nevertheless, ample literature has cited transitional justice as a single solution across the board (Loyle and Davenport, 2016) in a varied set of contexts, and criminal justice has been heralded by IGAD PLUS as a golden standard for South Sudan to deal with the massive impunity. Critical literature outlines that criminal justice in transitional contexts is never as simple as a case of a crime being committed and the perpetrators being brought to account. Instead, as has been experienced, it is a complex situation, and the pursuit of justice cannot be at the expense of peace.

This nagging debate has been reincarnated in the South Sudan case with even more force as it does not have the type of transition that transitional justice scholars envisage. Nonetheless, the IGAD PLUS successfully negotiated an agreement in 2015 and later revitalized the same provisions in 2018 with both agreements retaining a transitional justice chapter to deal with a truth telling process, reparations, criminal accountability and provisions for a hybrid court. Perhaps a crucial action was to build political consensus and keep the call for criminal accountability on the agenda. However, in the absence of a clearly defined transition, those to be tried by the HCSS would be the same people as those who are yielding power. It was then no surprise at all that in 2016 both the incumbent president and the leader of the opposition wrote an article stating that South Sudan should pursue reconciliation and not 
justice (Mamdani, 2016). The newspaper article was intended to influence the decisions of the key stakeholders to focus on reconciliation and not trials. The political leadership assumed that by controlling the narrative, criminal accountability would be dropped. In hindsight, their resistance to trials points to the fact that the same leaders accused of wrongdoing prefer to absolve themselves from possible prosecution. The resistance also highlights that no political or democratic transitions have taken place. It became clear that the transition that had been envisaged, but not defined, in the CPA had failed and since the Sudan People's Liberation Army (SPLA) became a breeding ground for the worst forms of violence, South Sudan needed a second transition, a political consensus and resources to tackle the impunity and violence. According to Mamdani, such a transition should seek to forge a political compromise at the level of society and the political elites, and should seek to gain political justice and political reforms (2016).

A context like South Sudan, where a transition failed and where transitions were only articulated in peace agreements and as short-term processes, was prone to further challenges. Firstly, the conflict is "on and off," even when a peace agreement has been signed. As peace was being mediated in Addis Ababa in 2014 and 2015, the parties overtly violated ceasefire arrangements and continued to stockpile arms for yet another offensive. The realization that trials were likely prompted the parties to the mediation to find ways to derail the peace negotiations. Secondly, from the perspective of IGAD PLUS the on and off and back and forth of the conflict affected the very production, use and dissemination of knowledge on the nature of the violence, human rights violations and recommendations for action against the perpetrators of violence. When IGAD PLUS coalesced around some key issues, the conflict re-erupted and a set of new issues came up again. This has been the case because every time IGAD PLUS made progress in resolving outstanding issues between the parties the conflict would resume and undo all the progress that had been made.

\section{IGAD'S LIMITATIONS IN CONCEPTUALIZING THE CONFLICT AND THE CONTEXT}

An analysis of IGAD's intervention in the Sudan-South(ern) Sudan conflict which culminated in the CPA and IGAD PLUS's intervention in South Sudan, which led to the 2015 ARCSS agreement, demonstrates a series of significant knowledge gaps. These gaps have shaped the way the violence has been understood, and importantly the way transitional justice was being debated and designed. In this section I outline the relevance of three key limitations in the way IGAD actors conceptualize the conflict and the context of their intervention: the framing of the conflict as an ethnic one between the two dominant tribes of Dinka and Nuer; a lack of consideration of the root causes 
of the conflict during the mediation; and a lack of analysis of whether criminal accountability is feasible in a non-transition context, i.e. where the same political elites have remained in power.

Firstly, the conflict was much more than that which had triggered the Dinka-Nuer showdown in December 2013. While the liberation struggles of the 1980s called for ethnic solidarity, the powerful elites who led the movement were split on whether to pursue a united Sudan or a new nation. At the start of the post-independence conflict, the violence had looked ethnic in nature because Juba was cleansed of some of its ethnic Nuer population. The intention of the perpetrators of the political violence was to divide the citizens along ethnic lines and "destroy any basis for consensus" (Mamdani 2016). However, there were in fact several other factors and divisions which had existed within the SPLM from the 1990s. During this time, the members of the SPLM leadership who called for democratic reforms fell out with the SPLM leader Dr. John Garang in 1991, which led to several internal problems and a near collapse of the SPLM. Consequently, the internal divisions within the SPLM led to several atrocities being committed against civilians by both the SPLM Nassir faction, ${ }^{3}$ led by Dr. Riek Machar, and the mainstream SPLM, led by Dr. John Garang. Eventually, IGAD dealt with the SPLM and the SPLM/ IO as separate entities, yet they were in many ways one and the same and had only splintered because of unresolved differences (De Vries and Schomerus, 2017). Additionally, political exclusion, discrimination and the government's habit of seizing communal land from smaller groups were contentious and long-standing issues relevant to analyses of the violence and yet missing from IGAD's mediation priorities.

In the process of negotiating the 2015 ARCSS the government of South Sudan, the opposition and the international community eventually made concessions to enable the parties to come to an agreement. The concessions bred a simplified narrative of what was occurring on the ground. South Sudan is multi-ethnic, but the Dinka and the Nuer make up nearly 57 percent of the population. The simplified version limited the issues of contention to ethnicity and a tribal war between the two dominant tribes. The interpretation and meaning given to the conflict meant that other grievances were seen as falling either with the Dinka-led government or with the Nuer-led opposition. There was no room to hear other grievances. The narratives of an ethnic fight made the resolution of the conflict seem easy. Most importantly, framing the conflict as such meant that the international community was only ready to deal with the recognized government led by the Dinka majority, and the opposition led by the Nuer. This approach has brought peace to South Sudan only on paper, without tangible improvements, because the grievances of other groups like the Equatorians, the Shilluk and the Fertit have not been addressed (De Vries and Schomerus, 2017). These include for example land grabbing, tribal 
dominance and their exclusion from the history of liberation, all of which fall outside of the main issues of the mediation and peace process (De Vries and Schomerus, 2017). So, at the time of the signing of the 2015 agreement there remained a series of important yet ignored issues. As a consequence, the quickly patched together agreement was abrogated almost immediately, in July of 2016. Its subsequent collapse was the starting point for a display of the intense geopolitics of the region (De Vries and Schomerus, 2017) which I discuss in further detail below. This strategy also meant that the primary stakeholders in the mediation were the same actors potentially implicated in any accounting for the past. In sum, IGAD's limited conceptualization of the causes and nature of the conflict, as well as the lack of analysis of the implications of the non-transition for accountability, would prevail over all of IGAD's criminal accountability and peacebuilding interventions in South Sudan (Kumalo and Lucey, 2017).

Secondly, and in a connected point, the IGAD mediation team failed to account for the root causes of the conflict, particularly around corruption and land disputes. Corruption, which had permeated the SPLM since its inception in 1983, included the diversion of food aid as a military strategy and established a system where humanitarian aid and financial resources could be misappropriated with impunity. This continued when the SPLM became the government and led to massive theft of government resources, including oil revenues from the CPA, activities which continue to this day. Corruption, coupled with no viable vision for post-CPA security, governance and institutional reforms, lowered the government's capacity to govern, and to manage localized conflicts triggered by competition over resources such as land, water or grazing land for animals, all of which had exacerbated insecurity in many pastoral areas and areas of farming communities, even before the 2013 conflict. Indeed, the misappropriation and sale of communal land without any consultations sat at the heart of the conflict. Land was supposedly sold to investors without any consultations with the communities and armed SPLA often grabbed communal land with undue regard for constitutional provisions on land, the Land Act or the Local Government Act (De Vries and Schomerus, 2017). SPLA military men used narratives of liberation as a benchmark to grab land and settle in spaces whose owners were considered by the SPLM/A as lesser contributors to the armed liberation struggle (Waal, 2014). The visible patronage networks, failed security sector reforms and rural insecurity, in the context of weak state capacity to manage such conflicts, did not form part of the core issues for mediation during the 2014 and 2018 peace talks (Rolandsen, 2015). The absence of these issues from IGAD's conflict analysis and approach to intervention reflects how IGAD was unable to grasp the depth of the problem (Waal, 2014) and thus they were also absent from the final text of the 2015 and 2018 peace agreements. 
Thirdly, there was a limited understanding of the political context in South Sudan and little to no analysis was done on whether criminal accountability in a situation where the same political elites are in power was a feasible option. This is despite reports on the conflict in South Sudan which have consistently implicated the leadership of the country in war crimes, as well as indicating that the leadership has benefitted from the war at the expense of the people (African Union 2015) - an aspect that will be discussed in more detail below.

\section{EXPANDING THE STAKEHOLDER POOL: KNOWLEDGE INTERVENTIONS AND POLITICAL EXPERTISE OF THE AU, UN AND TROIKA}

The peace process mutated several times as it went along, and it eventually encompassed a small secretariat consisting of Kenyan and Ethiopian aides, and experts to manage specific issues and to improve on country-specific knowledge and expertise. A small group from the UN mediation team in New York joined the mediation (Vertin, 2018). At the request of IGAD, Norway along with other European partners and the US offered to fund the process. Despite the readily offered financial support, coordination and expectations management there remained constant challenges (Vertin, 2018). In response to these challenges, IGAD eventually officially expanded the mediation team to include the UN, the AU and Troika. The expanded body came to be known as IGAD PLUS. The expansion of the mediation from IGAD to IGAD PLUS aimed to draw in more actors with expertise in supporting mediation and transitional justice initiatives and also to empower an IGAD that seemed too fraught and weak to deliver a peace deal on its own.

As stated earlier, IGAD was the first to intervene in the South Sudan crisis. It led the mediation process and, as an institution, retained its links with the member states in the region and drew on the member states as mediators, thus playing a pivotal role in setting the stage for understanding the violence and how to resolve it. For example, an IGAD Summit of Heads of State and Government was urgently convened in Nairobi, Kenya, in December 2013 because of the increasing ethnic undertones of the conflict and the widespread atrocities committed by the parties to the conflict. The heads of state present called for an immediate cessation of hostilities and for an inclusive dialogue. It was eventually decided that the South Sudanese parties should hold face-to-face talks, but the IGAD Heads of State communique left the details of the proposed plans to the foreign ministers of the respective IGAD states and a team of newly appointed envoys (Booth, 2016). The envoy from Ethiopia, Seyoum Mesfin, eventually led the mediation, deputized by a Kenyan, Lazaro Sumbeiywo. The addition of General Mohammed Ahmed Al-Dabi from the Sudan, after the communique was issued, marks the starting point of geopoliti- 
cal interests overtaking the process as his last-minute addition was undertaken to appease Khartoum. This was a concerning sign that the regional interests of the IGAD member states would take precedence over the content and objectives of the negotiations (Vertin, 2018).

The IGAD leadership had also clearly articulated their positions on the role of the AU and the UN as well as the wider international community as welcome partners in the search for peace and justice in South Sudan. The rationale for an IGAD-led peace process was widely shared, and both the AU's Peace and Security Council and the UN Security Council (UNSC) endorsed IGAD's leadership. As a regional hub of knowledge and with a niche in conflict mediation, IGAD was expected to engage with a more political understanding of each of its member states' contexts, since the region was often prone to vulnerabilities arising from high-level politicking and associated informal dynamics. The political and institutional dynamics of IGAD had been made more complex by the birth of South Sudan as a new nation, and IGAD began concerted efforts in working through a range of institutional reforms and in engaging the warring parties. While South Sudan, as a new nation, possesses little experience in political engagements, it remained highly attuned to the varying state agendas and interests within the region and among IGAD member states, using this to its advantage. Indeed, the ad hoc institutional arrangements of IGAD and IGAD PLUS, as well as its lack of specialized knowledge of the context and causes of the South Sudan crisis, offered a fertile landscape for the competing interests of the member states whose actions are as much informed by their self-interest as by the moral imperative to put an end to the suffering. Before IGAD was even able to deal with criminal accountability in South Sudan it first had to maneuver within the self-interest of states, regional dynamics and a history of reluctance to accept accountability of domestic constituencies (Byiers, 2016).

The involvement of South Sudan's immediate neighbors later proved to be problematic. Gradually, IGAD led the process and experts from the UN, the AU, the EU and South Sudan's biggest bilateral donors like the US, the UK, Norway and some select European actors and, to a small extent, China, supported the peace process. Drawing in South Sudan's neighbors, and informally engaging with the $\mathrm{AU}, \mathrm{UN}$ and Troika, proved to be a double-edged sword, because the multitude actors that make up IGAD PLUS worked independently and the coordination of approaches and outputs became a challenge. Moreover, these influential member states began to ignore reports and recommendations on the need for criminal accountability in order to further their own bilateral arrangements with South Sudan while sidestepping the thorny issue of systemic impunity (Vertin, 2018). 


\section{IGAD PLUS AND THE ENSUING POLITICS OF KNOWLEDGE}

The success of IGAD PLUS seemed almost instant, with the 2015 deal being reached immediately after the mediation team was expanded. The provisions of Chapter V - the transitional justice chapter - of the agreement articulated reconciliation and truth telling processes, reparations and compensation, and the establishment of the HCSS to deal with the massive impunity and the horrendous human rights violations in the wake of the conflict. While the establishment of the court was incumbent on the AU, the proposition of criminal accountability through the HCSS was a collective effort emanating from the combined expertise of IGAD PLUS. The details pertaining to enabling legislation, mandates of the court and the seat of the court were not included in this transitional justice chapter.

The provisions on the court sought to establish the HCSS through the AU. Many critics argued that the lack of detail in the provision of the court in the 2015 agreement was the start of the ambiguities and knowledge gaps that surrounded the establishment of the court, and leaving the details of the court to the AU and a transitional government that had expressed reservation regarding the formation of the court was a significant error. The South Sudanese parties were highly attuned to the politics of the region, and in most instances sought advantage and support from their regional friends. Eventually, after the transitional government was formed in Juba, the AU that was mandated to establish the HCSS faced difficulties in discussing details of the court with the political leadership in Juba, a leadership that was not interested in pursuing criminal accountability (Booth, 2016).

As soon as the HCSS was proposed, the issue of sequencing peace and justice was raised. A case in point was the release of the report of the AU Commission of Inquiry on South Sudan. The Commission had been established in 2014 by the AU in line with the AU transitional justice framework, which was being developed at the time, and which espoused its institutional intention to combat impunity and promote accountability and justice after mass atrocities. The AU transitional justice policy articulated measures which deal with justice, reconciliation and peace in a holistic manner. ${ }^{4}$ The policy sought to understand contexts of conflict states, diverse political situations, cultural nuances and values (African Union, 2019), all of which were relevant for the evolving situation in South Sudan. Tasked with the objective of investigating gross human rights violations, war crimes and crimes against humanity committed in the wake of the conflict, the Commission sought to balance peace and justice and deferred the release of the report until 2015 (Motsamai, 2017), thus engaging in the politics of timing. 
The commission's report had detailed massive human rights violations and made recommendations regarding the establishment of a court to try perpetrators. It was ready before the signing of the peace accord in November 2014, but there was an intense debate over whether the release of the conclusions would turn the South Sudanese leaders against the peace process (African Union, 2015). The debates regarding the timing of the release of the AU report of Inquiry on South Sudan illuminated some of the politics of knowledge which surrounded the mediation and also showed some of the difficulties encountered by multiple actors within IGAD PLUS, since IGAD PLUS was divided on the timing of the release of the report (African Union, 2015). Questions over whether criminal accountability would jeopardize anticipated transitions, reforms and the peace itself, continued to mar the course of the South Sudan criminal accountability discussions. Despite the debate on the timing of the release of the report, calls for criminal accountability were routinely made by the South Sudanese citizens, and civil society actors, in the face of reports on atrocious crimes committed (Booth, 2016). Despite AU experiences in South Sudan and its niche in understanding the context, the timing of the release of the report of its inquiry into the human rights violations was a tactical step, to delay the incriminating findings, in order not to jeopardize the peace process, but it was a serious miscalculation. While findings of the AU Commission of Inquiry on South Sudan documented serious human rights violations, the deferment of the release of the report shifted attention away from the suffering of the South Sudanese people to the difficulty of the peace mediation (Chonghaile, 2015). The AU Commission of Inquiry on South Sudan commenced its work at a time when the human rights violations were fresh and it was expected that evidence drawn from the report would be used to hold the perpetrators of violence accountable. So, upon its release at a much later date, in October 2015, its findings were less impactful and failed to draw attention to the human rights situation in the country (African Union, 2015).

Despite the politics involved in the delay of the release of the AU report of inquiry into the South Sudan conflict, the recommendations of the report paved the way for external stakeholders to push for the establishment of the HCSS. While the AU's mandate, to be undertaken jointly with the government of South Sudan, was to establish the HCSS to try perpetrators of atrocious crimes, the government of South Sudan was not, and is not, interested in criminal accountability. It was no surprise that, while transitional justice experts within the IGAD PLUS formation convened to flesh out the ARCISS provisions on the HCSS, violence erupted yet again in 2016. While the ARCISS 2015 and the currently revitalized version attempted to deal with impunity, the inadequate knowledge and understanding of the root causes of the conflict and extreme ethnic polarization discussed in the previous sections of this chapter frustrated efforts towards establishing the court. The following section 
highlights the regional politics that further hindered the implementation of the HCSS provisions of the ARCISS.

\section{REGIONAL GEOPOLITICAL IMPEDIMENTS TO THE ESTABLISHMENT OF THE HCSS}

The recommendation for a HCSS was made by the AU in its report of inquiry into the violence in South Sudan. The AU recommendation was eventually endorsed by IGAD PLUS. The proposition of a HCSS was envisaged to counter challenges faced by international courts which tend to have limited mandates and are usually difficult to access for the affected populations. A prominent example is the failure of the ICC to realize that by pursuing African heads of state it was triggering subsequent thoughts of withdrawal from the court by many African states, such as Burundi. ${ }^{5}$ Hybrid courts emerged in the late 1990s as a result of the failure of international courts. Hybrid courts, as an experiment of the UN, have been applied in post-conflict settings like Sierra Leone and Cambodia. They combine local and international legal expertise and were seen as positive elements to strengthen capacities and attract legitimacy. Human rights violations occurring in a state may attract international attention, but hybrid courts were regarded as the most effective mechanisms of dealing with the domestic situation in a state and also because they blend domestic actors while embracing international norms. Because of their presumed ability to help transition a fragile state to stability, it became natural that a HCSS was proposed for the situation in South Sudan - an option that provided great resonance because victims could be expected to have better access to the process (Andersen, 2017). However due to the divisive policies, political and economic interests in the region, the ample evidence of human rights violations failed to unite the actors to deal with impunity in the state (Carroll, 2013).

In 2017 IGAD released a communique of its intentions and support for the HCSS and in the same year the EU also encouraged the AU to move forward with the establishment of the court and applauded the recent extension of the UN Commission of Human Rights in South Sudan to preserve evidence of crimes committed. Clearly, a strong narrative was being supported by key actors that there had to be an end to the despicable violence. However, IGAD has been unable to lead the broad and well-articulated agenda necessary to devise clear instruments to enforce regional agreements and to sanction heads of states if needed. As an institution, IGAD's contribution to peace, justice and security in South Sudan is compromised by its weak institutional capacity and the internal politics of its member states, which constantly undermine its role as a Regional Economic Community (REC). The institution functions with few systemic and institutionalized approaches to addressing common 
regional interests (Byiers, 2016). Thus, while IGAD was seen to be adopting institutional reforms, in practice it functions through ad hoc processes, with frequent personalized involvement of heads of state. Geopolitical competition manifested in the form of support to armed proxies and other actions that affected the IGAD region in jointly lobbying for the HCSS. The geopolitical constraints not only manifested in actions that delayed the establishment of the court but also resulted in an intense politics of knowledge, including contestation of knowledge collated from reports on human rights violations, and led to a disregard of the findings on human rights violations by some of the member states within IGAD. For example, each of the member states was privy to and had access to reports authored by the members of IGAD PLUS regarding the human rights violations and recommendations regarding criminal accountability. However due to bilateral economic and military arrangements between the President of Uganda and the President of South Sudan, Uganda was least interested in the human rights track record of the government in Juba.

Another good example of geopolitical tensions which eventually undermined the call for criminal accountability is the political tension between the Sudan and South Sudan that led the President of South Sudan to seek alliances from Uganda to remain in power and to wage a successful war against the SPLM/IO, the main opposition and other armed groups. Despite the documentation of human rights violations by IGAD PLUS and Uganda's knowledge of human rights violations being committed, the Ugandan army with tacit US assistance rescued the government from a takeover by the opposition in 2013 and early 2014. Since then, Uganda remains the gateway for the transportation of ammunition to the government in Juba. IGAD, the UN and other South Sudanese civil society actors produced reports regarding the involvement of Uganda and called for the withdrawal of its armed forces to pave the way for the discussion of contentious issues around peace and justice, but Uganda remained adamant. The bilateral arrangements between Uganda and South Sudan undermined IGAD's push for accountability for human rights violations (IRIN, 2014). Uganda's military intervention was received with mixed feelings and while some argued that Uganda's intervention prevented South Sudan from an imminent collapse, critics argued that Uganda's deployment of its army in South Sudan meant it had taken sides with a government whose forces have committed atrocities against civilians. Critics also argued that Uganda benefitted financially from the deployment of its army to South Sudan and could not stand up against the massive human rights violations by the forces of the government. Reports by the UN also showed that the Ugandan forces were involved in the worst forms of human rights violations in South Sudan (IRIN, 2014), including, among others, the use of cluster bombs. Evidence of the use of cluster bombs by the Ugandan army was produced by UNMISS; however, 
both the Ugandan and South Sudan government denied the findings of the report (Human Rights Watch, 2014).

The Sudan was also involved in proxy wars and supporting rebels in South Sudanese territory. Several reports authored by the UN pointed to the role of the Sudan in supporting rebel groups in South Sudan, and before IGAD could exhaustively deal with this issue it asked the Sudan under President al-Bashir's leadership to support the 2018 peace negotiations. The involvement of the Sudan in mediating the peace in South Sudan was a double-edged sword as it was viewed as a way for the Sudan to benefit from the oil revenues and revamp its collapsing economy. Additionally, President al-Bashir was accused of genocide and was wanted by the ICC. Thus, considering his own track record of human rights violations, there was no way he could consider the criminal accountability demands of the South Sudanese people. Hence the two countries of Uganda and the Sudan, themselves accused of committing human rights violations, were mandated by IGAD to pressure the two South Sudanese political leaders into agreeing to a settlement (Knopf, 2018).

Meanwhile, Uganda and Ethiopia constantly competed to dominate the region. Recent unrests in Ethiopia and the death of Meles Zenawi, the former Prime Minister of the country, left a vacuum that Uganda felt it could exploit and fill as a regional leader. These developments fueled Museveni's ambitions of replacing Ethiopia as the head of the IGAD. Consequently, he was quick to deploy his army into South Sudan in 2014 and 2015, through a bilateral diplomatic arrangement which obstructed the role of Ethiopia and the efforts of an IGAD-led mediation of the peace process. In fact, Uganda's interventions took place outside of the Ethiopian-IGAD-led initiatives. Clearly, geopolitical constraints between some of the states of the IGAD region led to parallel, bilateral processes which inhibited the region from providing a united response to the justice demands.

South Sudan was also the object of competition between Egypt and Ethiopia over the waters of the Nile. Egypt became the only regional state not to side with Ethiopia over the dispute in South Sudan, and for this reason the leadership in South Sudan exploited these tense relationships to side with Egypt (Knopf, 2018). Egypt in return used its seat at the UNSC and its seat on the AU Peace and Security Council, in 2015 and 2017 respectively, to deflect pressure from Ethiopia and others. Despite knowledge of human rights violations by the South Sudan state which had been collated from several reports of the UN and the AU, Egypt continued to front its economic interests at the expense of justice in South Sudan.

To provide one last example, recently the Sentry Report (2018), in a bid to push the IGAD member states to act against impunity in South Sudan, detailed the top leadership's involvement in and profiteering from oil money and their practice of banking on the war to amass resources for themselves. The report 
urged Kenya and Uganda to target real estate connected to South Sudanese political leaders. It was envisaged that the financial pressure would disrupt the lavish lifestyle of South Sudanese officials and their families. As argued earlier, and due to the political and economic interests of Uganda and Kenya in South Sudan, the two states ignored the recommendations made by the Sentry Report (Sentry, 2018).

These interesting dynamics and politics in the region robbed IGAD PLUS of the possibility for much needed collective action on issues of justice in South Sudan (Knopf, 2018). For instance, to make a case for justice, through the HCSS, both the AU, the UN, the IGAD and Troika and other verification teams like the JMEC authored reports and made recommendations to IGAD about the massive human rights violations that occurred in the wake of the conflict, but the political and economic interests of the member states of the IGAD inhibited the region from jointly pushing for the establishment of the HCSS. In fact, despite having knowledge of the human rights violations, each of the member states within IGAD constantly undermined the recommendations and decisions of IGAD on the establishment of the HCSS.

Troika as an actor of the international community cannot be excluded from the politics and interests in the region and in South Sudan in particular. Initially, the intention of expanding the mediation of the 2015 agreement was to strengthen the mediation, fill in knowledge gaps and to bring in a myriad of expertise on peacemaking and justice (Booth, 2016). Troika had joined the mediation process as guarantors, and to finance the process. The EU, the US, Japan and China had always had influence in the IGAD region. While the financial support offered to the IGAD by Troika suggested that the IGAD region was a legitimate partner to these countries, it nonetheless highlighted the complexities of a series of networks and alliances which could affect the politics of knowledge. While IGAD was seen as the driver of its own regional agendas on peace and security, it nonetheless was financially dependent on some of the powerful nations from whom it derived financial support. Owing to the financial dependency on and influence of Troika, IGAD was seen by the South Sudanese political leadership as furthering foreign agendas and policies and not its own. Therefore, despite ample evidence collated from reports authored by the UN, the AU, JMEC and civil society regarding the human rights violations and the worrisome levels of impunity exhibited by both the government and opposition forces, the South Sudanese political leadership was attuned to the financial assistance provided by Troika and often accused the IGAD of furthering the agenda of Troika. Eventually the South Sudanese parties referred to the peace agreement and the transitional justice chapter as a foreign agenda intended to change the regime in Juba (Byiers, 2016).

The UNSC members, led by the US and the UK, sought to move forward on multilateral sanctions against South Sudanese individuals seen to be obstruct- 
ing peace and justice, but on many occasions there was very little support from IGAD member states and some of the permanent members of the UNSC. For instance, even after evidence of human rights violations was documented in reports of the IGAD PLUS and other verification teams of JMEC, IGAD member states with vested economic interests in South Sudan, notably Kenya and Uganda, chose to overlook the veracity of the human rights situation and the need to pressure the South Sudan rivals to make concessions, and they vetoed international action. Despite the push for punitive action, the US declined to press for an arms embargo. The UN Special Envoy for the Sudan and South Sudan was based in Addis Ababa and had access to all the reports on South Sudan and served as an advisor to the process, but it failed to push the parties to agree to the court because there was no general regional support. The Special Representative of the Secretary-General in South Sudan was privy to various reports but was frustrated by her distance to the process in Addis Ababa. Troika and the EU provided funding and the EU imposed sanctions against individuals. Despite the pressure from IGAD PLUS, the geopolitical interests of the IGAD member states and the actions of some members of the UNSC resulted in a situation where some of the knowledge on human rights violations was either contested by others or was completely overlooked (Vertin, 2018).

\section{KEEPING CRIMINAL ACCOUNTABILITY ON THE AGENDA: THE ROLE OF IGAD PLUS IN INFORMATION DISSEMINATION}

The reports of the AU, the UN, Troika and JMEC which consistently indicated that both parties to the conflict have committed human rights violations against civilians also made recommendations on how to deal with the impunity by proposing the HCSS, but as argued earlier the politics of the region led some of the IGAD member states, and some of the members of the UNSC, to overlook some of the recommendations made regarding the proposed court. For instance, in 2018 the AU Peace and Security Council issued a communique on South Sudan, warning that it would consider other steps, including sanctions, should the South Sudanese parties further delay the establishment of the court. ${ }^{6}$ The US permanent representative to the UN issued similar threats and warned of sanctions if the government does not live up to its pledges. ${ }^{7}$ In early 2017, the AU held consultations with the Ministry of Justice in South Sudan, which led to a draft statute of the court and draft memorandum of understanding between the AU and the South Sudanese government (Human Rights Watch, 2017). Both documents were submitted to the South Sudan Council of Ministers, but at the time of writing this chapter there has been no action yet. The AU pushed the South Sudanese government to complete its 
part of the agreement or face sanctions. However, some government officials told Human Rights Watch that a number of key minsters in government were opposed to the court. Human Rights Watch noted that if a credible, fair and independent HCSS was not established the ICC could be made an option. This strong statement from Human Rights Watch comes against the backdrop of the shared frustrations regarding the lack of action by the South Sudanese political leadership and also some of the weaknesses within the IGAD region and the AU (Human Rights Watch, 2017).

The UN Commission on Human Rights in South Sudan, which was established in March 2016, authored reports and urged the South Sudan government to create the HCSS to adjudicate war crimes. In light of the signing of the revitalized agreement in 2018, the UN Commission urged the government to utilize the opportunity created by the revitalized agreement to ensure that justice and accountability for the victims of the many crimes committed during the war are realized. Yet 24 hours after the signing of the peace agreement, verification teams reported fighting in other parts of the country. The UN Commission noted that the only way for the government to realize peace would be to provide justice to the many victims affected by the war. The commission also urged the AU and the government of South Sudan to expedite plans to form the HCSS. Despite these calls, the government has blocked the AU's ability to set up the court. It is therefore critical that IGAD, the UN and the AU deal with the underlying politics of the region that made some of the member states overlook recommendations regarding the HCSS, and also to ensure that the AU does not get drawn into the politics of the region (Tomlinson, 2018).

Troika nations, which formed part of the IGAD PLUS, made similar calls for the establishment of the HCSS, which were not heeded by the government. While the HCSS was proposed as the best option if South Sudan was to realize a long-lasting peace, the question remains as to whether the incumbent leadership will pave the way for the establishment of the court and if the leadership will allow the court to try any of the current leadership implicated in war crimes. The politics of knowledge within IGAD member states and the delay tactics of the South Sudan government aside, the real question and the real test is whether the AU Assembly of Heads of State and Government will draw up legislation for the HCSS that enables it to try South Sudanese leaders implicated in crimes. The 2015 agreement provided that the creation of the HCSS should not be impeded by a statute or constrained by any statutes of limitation or the granting of pardons, immunities or amnesties. On the other hand, the AU developed the immunity principle for sitting heads of state and senior government officials which led to the inclusion of an immunity clause in the Protocol on the Statute of the African Court of Justice and Human Rights, which in previous drafts did not have an immunity clause (African Union, 2014). This came after the ICC issued an arrest warrant for al-Bashir 
of the Sudan (Institute for Security Studies, 2016). Additionally, the AU had perceived that the prosecution of sitting heads of state or government officials would constitute a threat to state stability as seen in the AU's desperate efforts to save Kenya, when its leadership was taken to the ICC. It is to be noted that the AU had instituted an inquiry into a collective withdrawal from the ICC based on the differences over immunity and the fact that the court, at the time, had targeted African states only.

The South Sudanese leadership is attuned to the provisions of the 2015 agreement prohibiting pardons and amnesties and also attuned to the AU's immunity principle for sitting heads of state and senior government officials. The two contradicting positions of the 2015 agreement and of the AU proved to be one of the obstacles to dealing with impunity in South Sudan (Institute for Security Studies, 2016). It may also seem like the IGAD member states' leadership is not interested in criminal accountability.

\section{CONCLUSION: LOOKING FORWARD FOR THE HCSS}

In summary, this chapter discussed the difficulties IGAD faced in dealing with knowledge gaps and the ensuing politics of knowledge within the IGAD region, while attempting to address the root causes of the conflict in South Sudan. The chapter also enumerates additional challenges faced by the reconstituted body of IGAD PLUS in designing transitional justice processes, especially those calling on criminal accountability through a HCSS. The chapter also argues that in order to address its own knowledge gaps, the politics of knowledge around the roots of the conflict, and the most responsive transitional justice mechanism, IGAD PLUS drew on the expertise of its membership and expanded mandates to ensure that discussions about criminal accountability remain on the transitional justice agenda.

IGAD, and later IGAD PLUS, intervened to resolve the conflict in South Sudan and to ensure that transitional justice, especially criminal accountability through the HCSS, was an integral part of the peace agreement. However, conceptualizing the conflict as ethnic, and as one between two dominant tribes, meant that reports on the myriad of issues and roots of the conflict were left outside of the framework of the negotiations and outside of plausible solutions to the conflict, leaving significant gaps in how the international community conceptualized and intervened in the conflict. While IGAD PLUS was preoccupied with dealing with impunity and ending a conflict that was characterized with massive human rights violations, available knowledge on the roots of the conflict, on the trajectory of South Sudan's conflicts, and on the consequences of the unfolding impunity was not adequately used to resolve the conflict. Hence, IGAD PLUS struggled to mediate the conflict and is struggling with ensuring that criminal accountability against those perpetrators who commit- 
ted atrocities is realized for the victims of human rights violations (De Vries and Schomerus, 2017).

While the re-composition of IGAD PLUS was significant in pushing the South Sudanese warring parties to sign an agreement in 2015, the agreement was immediately abrogated in 2016. It was later revitalized in 2018, retaining the chapter on transitional justice, including criminal accountability through a hybrid court. While the truth telling processes, like the national dialogue and the consultations on the establishment of the Commission for Truth, Reconciliation and Healing (CTRH), are ongoing, the process of establishing the HCSS has been painfully slow. While the AU, the UN, the EU, the US and the UK urged the government of South Sudan to make good on its promise to establish the court to try perpetrators of gross human rights violations, little progress has been made, largely because the very leaders implicated in wrongdoing are the same ones making decisions regarding the court (Knopf, 2018).

Knowledge on the underlying regional geopolitics and some of the dynamics and interests of the IGAD and the politics within and among Troika members have not been adequately incorporated to ensure that the region is in support of the establishment of the court and does not work against its establishment. The IGAD member states are showing less and less interest in criminal accountability because of their interests in the economic resources of South Sudan and in the political leadership of the region. The politics of the region thus have inhibited the establishment of the HCSS (Knopf, 2018). It will be impossible to curb impunity in South Sudan without criminal accountability. It is therefore essential that trials, implemented through the HCSS, send a strong message to perpetrators of human rights violations in the wake of the conflict (Institute for Security Studies, 2016). The government's policies of blanket amnesties and pardons have sent the wrong message to perpetrators of violence. The amnesties have conveyed the message that there is a reward for waging war and committing atrocities and that mindset should end in the situation in South Sudan if peace and justice are to be realized. While IGAD PLUS is aware of such amnesties being awarded to those waging war and committing atrocities, this has not been addressed directly with the government or the opposition (Deng, 2014).

The HCSS must be established and the perpetrators must account for their crimes. For a start, several reports, including the Sentry report, had rallied the IGAD member states to target properties of government officials who have profited from the spoils of war and those government officials who have accumulated unexplained wealth within a short period of time. Such measures would force the government to prioritize peace and justice (Sentry, 2018). It is also pertinent that the pressure coming from the UN, the AU and the international community is maintained so that criminal accountability is always on the South Sudan agenda. Despite these recommendations for action, the 
government continues to play delay tactics hoping that IGAD PLUS drops the idea of criminal accountability. So IGAD PLUS should always be attuned to these internal South Sudanese politics (Institute for Security Studies, 2016).

South Sudan as a complex, non-transition context, suffering from recurrent wars and cycles of human rights violations, is a difficult and risky environment for the production, use and dissemination of knowledge about human rights violations. With failed transitions hailing from the CPA and the 2015 and 2018 revitalized agreements, the current leadership constitutes the transitional government and will obstruct criminal accountability at all costs. IGAD PLUS remains acutely aware of the impediments of dealing with contexts where transitions have not occurred and it is crucial that an analysis of the context informs some of the next steps to ensure that interventions based on the actual situation on the ground are tailored as a response to the impasse. IGAD PLUS was aware that mechanism of the HCSS would be highly contested by the incumbent leaders, but it failed to address some of the deliberate sabotaging actions of government emerging from recommendations collated from reports. Grim as the situation might be, the crimes committed are not subject to a statute of limitations, which is a remarkable legal standpoint. The UN Human Rights Commission on South Sudan also called for the preservation of evidence so that when the time comes and the court is established, the evidence will be used to try the perpetrators of war crimes (Institute for Security Studies, 2016). The role of the international community remains crucial if the government continues to frustrate the establishment of the HCSS. If criminal accountability will not be realized for victims, the ICC should be considered as an option. Even though South Sudan has not ratified the Rome Statute, the peace agreement can be used as a binding instrument to refer the case to The Hague (Kumalo and Lucey, 2017).

The role of South Sudanese civil society groups and other political groups remains crucial in keeping the criminal accountability calls on the agenda, despite the challenges. They continue to produce reports and make recommendations on how IGAD PLUS can deal with some of the obstacles. Ending impunity for all crimes including conflict-related sexual and gender-based violence is the only way to end the widespread practice. Civil society organizations in South Sudan have become the agents who relentlessly call for criminal accountability, and they are being heard by the international community (Sooka, 2018). The deeply entrenched pattern of impunity is because, for so many years, perpetrators of violence, including sexual and gender-based violence, got away with it (Reliefweb, 2019).

Lastly, the UN Commission for South Sudan was set up in 2016 by the UN Human Rights Council to determine the facts and circumstances of the violations and also to collect and preserve evidence. The civil society organizations had a chance to speak with the Commission and their knowledge of the patterns 
of the crimes has fed into the UN system that collects and preserves evidence. There is a team of researchers and investigators who speak to the communities and the civil society organizations in South Sudan. The UN Commission has also extended its visits to other states of South Sudan, outside of Juba, for an opportunity to speak with victims and communities that are based out of the capital and to get a clear perspective of some of the crimes that have occurred. This is generating a wealth of knowledge which will eventually be used to try perpetrators of war crimes. The AU, which is tasked with the establishment of the HCSS, will tap into the knowledge already being collected by the UN Commission on Human Rights in South Sudan (Sooka, 2018). All victims have unanimously called for criminal accountability for what has been done to them by the armed forces and it is the duty of IGAD PLUS to ensure that the HCSS is established, or alternatives, which look to international courts, are explored. There will be no peace in South Sudan without justice (Institute for Security Studies, 2016).

\section{NOTES}

1. The members of IGAD are Djibouti, Ethiopia, Somalia, Eritrea, the Sudan, South Sudan, Kenya and Uganda.

2. IGAD PLUS includes the members of IGAD and the United Nations (UN), the African Union, the African Union Commission, China, the European Union and Troika which in turn consists of Norway, the UK, the European Union (EU), the US and, to a small extent, China. This will be elaborated below.

3. The Nassir faction was a breakaway faction led by Dr. Riek Machar after a split from the main SPLM in 1994. The spilt had occurred due to the disgruntlement of a section of senior SPLM cadre who felt that Dr. John Garang, the former leader of the SPLM, was being dictatorial.

4. For a further discussion of the politics of knowledge of the AU transitional justice policy process please see Chapter 9 by Ulrike Lühe in this book.

5. Burundi became the first African state to withdraw from the ICC, alleging that the ICC deliberately targeted Africans for prosecution (BBC, 2017).

6. Communique of the 786th African Union Peace and Security Council Meeting on South Sudan, 15 May 2018, accessed 24 March 2020 at http://www.peaceau.org

7. 'U.S. Envoy Urges S. Sudanese Parties to Renounce Violence', The Sudan Tribune, accessed 24 March 2020 at https://www.sudantribune.com/spip.php ?article 68167

\section{REFERENCES}

African Union (2014), Protocol on Amendments to the Protocol on the Statute of the African Court of Justice and Human Rights, Addis Ababa: African Union.

African Union (2015), The Final Report of the African Union Commission of Inquiry on South Sudan, Addis Ababa: African Union. 
African Union (2019), African Union Transitional Justice Policy, accessed 24 March 2020 at https://au.int/sites/default/files/documents/36541-doc-au_tj_policy_eng web.pdf

Andersen, H. (2017), 'Hybrid Courts and Multilevel Rules of Law: Some Overall Considerations, Challenges and Opportunities', International Journal of Criminology and Sociology, 6 (12), 117-26.

Arthur, P. (2009), 'How "Transitions" Reshaped Human Rights: A Conceptual History', Human Rights Quarterly, 3 (2), 321-67.

BBC (2017), 'Burundi leaves International Criminal Court amid row', BBC News, accessed 24 March 2020 at https://www.bbc.com/news/world-africa-41775951

Booth, D. (2016), South Sudan's Peace Process: Reinvigorating the Transition, London: Chatham House, The Royal Institute of International Affairs.

Byiers, B. (2016), The Political Economy of Regional Intergration in Africa: Intergovernmental Authority on Development, Maastricht: ECDPM.

Carroll, C. E. (2013), 'Hybrid Tribunals are the Most Effective Structure for Adjudicating International Crimes Occurring Within a Domestic State', Law School Student Scholarship, 90, 1-25.

Chonghaile, C. N. (2015), 'Conflict and Arms: African Union Must Release South Sudan Report, Rights Groups Say', The Guardian online, accessed 24 March 2020 at https://www.theguardian.com/global-development/2015/feb/04/african-union -report-south-sudan-delayed

Deng, D. (2014), 'Special Court for Serious Crimes: A Proposal for Justice and Accountability for South Sudan', South Sudan Law Society, accessed 24 March 2020 at https://www.cmi.no/file/2760-SSLS-SCSC-Proposal-for-a-Hybrid-Court .pdf

Dessalegn, A. G. (2017), 'The Cause and Consequence of Conflict in South Sudan', International Journal of Political Science and Development, 5 (1), 15-21.

De Vries, L. and M. Schomerus (2017), 'South Sudan's Civil War Will Not End with a Peace Deal', A Journal of Social Justice, 29 (3), 333-40.

Human Rights Watch (2014), 'South Sudan: Investigate New Cluster Bomb Use', Human Rights Watch Online, accessed 24 March 2020 at https://www.hrw.org/ news/2014/02/14/south-sudan-investigate-new-cluster-bomb-use

Human Rights Watch (2017), 'South Sudan: Stop Delays on Hybrid Court', Human Rights Watch Online, accessed 24 March 2020 at https://www.hrw.org/news/2017/ 12/14/south-sudan-stop-delays-hybrid-court

Institute for Security Studies (2016), Will the Hybrid Court for South Sudan Ever Try the Current Leadership?, Pretoria: Institute for Security Studies.

IRIN (2014), Doubts over Uganda's Military Intervention in South Sudan. IRIN, accessed 27 March 2020 at http://www.thenewhumanitarian.org/analysis/2014/01/ 17/doubts-over-uganda-s-military-intervention-south-sudan

Knopf, P. (2018), South Sudan's Civil War and Conflict Dynamics in the Red Sea, Washington, DC: USIP.

Kumalo, L. and A. Lucey (2017), How the AU Can Promote Transitional Justice in South Sudan, Oslo: Institute for Security Studies.

Loyle, C. and C. Davenport (2016), 'Transitional Injustice: Subverting Justice in Transition and Postconflict Societies', Journal of Human Rights, 15 (1), 126-49.

Mamdani, M. (2016), 'Who's to Blame in South Sudan?', Boston Review Global Justice, accessed 24 March 2020 at http://bostonreview.net/world/mahmood-mamdani-south -sudan-failed-transition 
Motsamai, D. (2017), 'Assessing AU Mediation Envoys: The Case of South Sudan', East Africa Report, 10, 1-12.

Reliefweb (2019), Prosecuting Sexual and Gender-Based Crimes in South Sudan is Challenging but is Essential for Peace, Addis Ababa: Reliefweb.

Rolandsen, Ø. H. (2015), 'Another Civil War in South Sudan: The Failure of a Guerrilla Government', Journal of East African Studies, 9 (1), 163-74.

Rothe, M. (2007), 'Darfur and the Politicization of International Law: Genocide or Crimes against Humanity', Humanity \& Society, 31 (1), 85-101.

Sentry (2018), 'The Sentry Urges Kenyan and Uganda Authorities to Target Real Estate Connected to South Sudanese Officials', Sentry Press Release, accessed 24 March 2020 at https://thesentry.org/2018/06/12/2003/sentry-urges-kenyan-ugandan -authorities-target-real-estate-connected-south-sudan-officials/

Sharp, D. N. (2015), 'Emancipating Transitional Justice from the Bonds of the Paradigmatic Transition', International Journal of Transitional Justice, 9 (1), 150-69.

Sooka, Y. (2018), 'Opening Remarks by the Chairperson of the Commission on Human Rights in South Sudan at Press Conference UNMISS HQ, Tomping, Juba', United Nations Human Rights Council, accessed 24 March 2020 at https://www.ohchr.org/ EN/HRBodies/HRC/Pages/NewsDetail.aspx?NewsID=23998\&LangID=E

Tomlinson, A. (2018), 'UN Urges South Sudan Government to Create the Hybrid Court for War Crimes', Jurist.org, accessed 24 March 2020 at https://www.jurist .org/news/2018/09/un-urges-south-sudan-government-to-create-a-hybrid-court-for -war-crimes/

Vertin, Z. (2018), A Poisoned Well: Lessons in Mediation from South Sudan's Troubled Peace Process, New York: International Peace Institute.

Waal, A. de (2014), 'When Kleptocracy Becomes Insolvent', African Affairs, 113 (452), 347-69. 